\title{
Determinants of Economic Growth in the European Union. An Empirical Analysis of Conditional Convergence
}

https://doi.org/10.21272/sec.5(2).26-34.2021.

Ana-Maria Holobiuc, ORCID: https://orcid.org/0000-0001-9329-9758

PhD Candidate, Bucharest University of Economic Studies, Romania

\begin{abstract}
Being established from the initiative of six visionary countries in the second half of the $20^{\text {th }}$ century, the European Economic Community has shifted the history of the European continent by promoting economic collaboration and political stability. Given its initial success, the regional group has quickly evolved from customs union to Economic and Monetary Union, comprising nowadays twenty-seven European countries. Although the European Union has successfully managed political, economic, social and even sanitary turmoil, the stability of the European architecture continues to be threatened by the heterogeneity of its members. In this respect, one of the main challenges for the European Union in its current composition aims the convergence of the economic performance between countries and regions. The purpose of this paper is to study the economic growth patterns in the European Union during 2000 and 2019, also conducting a comparative analysis between New and Old Member States. In order to capture the European economic landscape, the methodology was based on conditional $\beta$-convergence and the estimates were conducted by using ordinary least squares and generalized least squares with fixed effects. We have tried to find the relationship between the lagged value of GDP per capita and the subsequent growth rates, but also to study the influence of macroeconomic and social-related variables. By estimating regressions based on panel data, we have found evidence in favor of income convergence in the European Union, based on the inverse relationship between the lagged value of GDP per capita and the annual growth rates. Moreover, the comparative analysis between the New and Old Members illustrated that convergence was stronger in the latter group, given the sound macroeconomic and social environment. The empirical analysis suggested that the economic growth process both at aggregate and subgroup level was enhanced by investment, exports of goods and services, sound public finances and the increase of percentage of population with tertiary education. Consequently, in order to increase the cohesion between Members and to avoid separatist movements, the European decision-makers should strengthen the macroeconomic and social frameworks, maintaining a sustainable economic growth trajectory for both the New Members from Central and Eastern Europe and the Old Member States.
\end{abstract}

Keywords: European Union, economic growth, $\beta$-convergence, panel data analysis.

JEL Classification: O40, O52, O57.

Cite as: Holobiuc, A.-M. (2021). Determinants of economic growth in the European Union. An empirical analysis of conditional convergence. SocioEconomic Challenges, 5(2), 26-34. https://doi.org/10.21272/sec.5(2).26$\underline{34.2021 .}$

Received: 23.03 .2021

Accepted: 25.05 .2021

Published: 25.06.2021

Copyright: (C) 2021 by the author. Licensee Sumy State University, Ukraine. This article is an open access article distributed under the terms and conditions of the Creative Commons Attribution (CC BY) license (https://creativecommons.org/licenses/by/4.0/).

\section{Introduction}

The establishment of the European Economic Communities in the 50s has represented the preface of a successful integration story that has decisively influenced the historical course of the European continent. Being initially 
founded by six West European countries with the purpose to strengthen the economic ties and prevent the political conflicts that affected the regional and stability during the second half of the $20^{\text {th }}$ century, the European Union comprises nowadays twenty-seven members under the principles of Economic and Monetary Union. The enlargement process, which started in 1973 has created both opportunities and challenges for the European group. On the one hand, the accession of other European countries consolidated the economic and political power of the European Union, as well as its influence in international organizations. On the other hand, the accession of the Mediterranean countries and more recent of the Central and Eastern European group could threaten the status quo of the European Union, given the diversity of the economic and social frameworks of the newcomers. One of the main principles that was established in the Treaty of Rome (1957/1958) and which continues to be strictly preserved nowadays aims the cohesion between countries and regions. In this respect, the European Union has the difficult task to assure prosperity for all its members and the economic emancipation of the less developed countries and regions.

The purpose of this paper is to capture the economic growth patterns in the European Union between 2000 and 2019 , trying to find evidence in favor of $\beta$-convergence hypothesis. We have estimated conditional $\beta$-convergence using ordinary least squares and generalized least squares methods, based on panel data, for European Union (28) and two subgroups of countries - the New Members from Central and Eastern Europe and the Old Members or EU (15). The study is based on the conditional $\beta$-convergence model, which assumes that economies are not homogenous in terms of structural characteristics and may reach different states of equilibrium. Consequently, it is necessary to include in the regression equations, besides the initial level of GDP per capita, other economic, social or/and institutional variables in order to control the differences between economies. The results of panel regressions confirm the conditional $\beta$-convergence hypothesis both at aggregate and subgroup level, given the inverse relationship between the lagged value of GDP per capita and the subsequent growth rates. Moreover, the study has some political implications. Firstly, it suggests that decision-makers should increase the investment, as reflected by the gross fixed capital formation, as well as to continue the efforts of liberalization at bilateral and multilateral level in order to rise the volume of exports of goods and services with the third countries. In the field of budgetary framework, the empirical research illustrates that maintaining a positive government balance would enhance the economic growth. Last but not the least, the study suggests that the efforts to increase the percentage of population with tertiary study have positively influenced the economic growth patterns.

The paper is structured as follows. Section 2 comprises the review of the relevant empirical studies in the field of economic growth and convergence, with special focus on European Union. Section 3 presents the methodology of the research, as well as the descriptive statistics of the variables, while section 4 illustrates the results of the empirical study. Lastly, we have discussed the results and implications of the study and proposed future directions of research.

\section{Literature review}

In the $20^{\text {th }}$ century, exponents of the neoclassical model have initially tried to explain the process of economic growth based labor and capital, complemented by the technological progress that was exogenously determined. In the empirical framework developed by Solow (1956) and Swan (1956), developing economies would experience higher GDP per capita growth rates than the advanced ones, reaching a common state equilibrium in the long run. Consequently, the neoclassical growth model was based on the hypothesis of decreasing return to capital, which involved a reallocation of capital stocks from advanced to less developed economies, with higher profitability in this production factor. Although the neoclassical growth model captures the role of capital and labor and explains the catching-up process based on technological process, exogenously determined, it also has some shortcomings. First of all, it fails to explain why the least developed economies, mainly from the African continent cannot converge towards the level of the developed economies such as US. Furthermore, the SolowSwan model is founded on the assumption that all economies will reach the same state of equilibrium and that decision-makers and entrepreneurs don't play an active role in influencing the growth path. However, recent evidence suggest that public policy can catalyze economic growth, through investment, trade and R\&D. In order to manage some of the shortcomings of the neoclassical growth model, researchers such as Romer $(1986,1990)$, Lucas (1988) and Grossman \& Helpman (1994) laid the foundation of the endogenous growth model. The 
exponents of the endogenous growth model extended the neoclassical framework and took into consideration the role of decision-makers in creating a favorable environment for convergence. Romer (1986) illustrated that economies of scale have an important role in supporting economic growth and convergence. Moreover, Lucas (1988) and Romer (1990) highlighted the role of technological progress, as an endogenous factor, in catalyzing economic growth. A defining feature of these models derives from the possibility of maintaining high productivity gains and economic growth on the long run, as a result of investments in human and physical capital. In other researches, Romer $(1987,1989)$ brought to the forefront the role of specialization in generating productivity gains and the positive impact of the human capital that includes not only physical but also intellectual abilities.

The empirical studies in the field of economic growth and convergence are mainly based on two complementary instruments developed by Barro and Sala-i-Martin (1992). $\beta$-convergence aims a potentially negative relationship between the initial level of income and the subsequent growth rates, while $\sigma$-convergence is used by researchers in order to examine the evolution of differentials between economies. Moreover, from the empirical studies conducted by the neoclassical and exogenous growth model researchers resulted two main perspectives on $\beta$ convergence: absolute and conditional. De la Fuente (1997) noted that absolute $\beta$-convergence implies that less developed economies register higher growth rates, achieving a common state of equilibrium in the long run. In contrast, conditional $\beta$-convergence presumes that economies may reach different states of equilibrium, this perspective being compatible with the theories that predict increasing of polarization between developed and poor economies increase. According to Duro (2012), absolute convergence assumes that less developed economies register higher returns on capital, attracting investments that enhance the catching-up process. In contrast, the conditional model takes into consideration the tendency of less developed countries towards spending, to the detriment of investments and the higher risk premium that could limit the investment decision in these economies. Duro notes that the study of the relationship between the initial level of GDP per capita and subsequent growth rates can be conducted on conditional model by controlling the variables considered representative in the process of economic growth. Taking into consideration the potential structural differences between the European Member States, the current study focuses on conditional $\beta$-convergence. Referring to the empirical framework, Islam (2003) highlighted that regressions based on cross-sectional, panel and time series data are used to determine $\beta$ convergence (absolute or conditional). However, Islam noted that the cross-sectional regressions used in the study of economic growth patterns have a number of vulnerabilities. Of these, perhaps the most significant is the use of an average value for each economy, which leads to a biased estimate of the convergence rate. At the same time, another problem that derives from the use of cross-sectional data is determined by the possibility of omitting relevant variables. In order to manage some of these vulnerabilities, Islam suggested the use of panel data and estimating the regressions by taking into consideration the individual effects of countries or regions.

Based on the economic growth theories, developed in $20^{\text {th }}$ century, contemporary researchers have examined the European Union's landscape by taking into consideration the absolute and/or conditional $\beta$-convergence. Particularly, more and more studies have been devoted in the last two decades to the European regional group, analysts trying also to conduct comprehensive studies between the New Members from Central and Eastern Europe and the Old Members. Stanišić (2012), Dobrinsky and Havlik (2014), Chapsa et al. (2015), Marelli et al. (2019), Rapacki and Próchniak (2019) conducted studies that take into consideration the conditional model, analysts including in the empirical analysis, besides the initial/lagged value of GDP other explanatory variables related to macroeconomic, social or institutional framework. For example, Marelli et al. (2019) estimated conditional $\beta$-convergence based on cross-sectional data between 1995 and 2016, identifying divergent trends in the Eurozone (EU - 15). Extending the sample to 27 Member States, Marelli et al. identified a convergence rate around 4\%, mainly reflecting the high performance of the group of New Member States. According to Marelli et al., Eurozone membership did not influence the results of the study. Taking into consideration the problem of endogeneity, analysts also estimated conditional convergence using the Generalized Method of Moments (GMM) based on panel data, identifying a convergence rate of about $1.8 \%$ for the Eurozone and $2.1 \%$ for the European Union. Similarly, Chapsa et al. (2015), studied conditional convergence in the case of the EU (15), including both economic variables and indicators representative of the institutional framework (bureaucracy and corruption). Analysts found evidence in favor of income convergence within the EU (15), concluding that factors such as investment in human and physical capital and trade openness had a positive influence on economic growth. 
According to Chapsa et al., corruption is negatively correlated with the process of economic growth, while bureaucracy affects economic growth especially in the case of cohesion countries. Similarly, Dobrinsky and Havlik (2014) studied conditional convergence based on cross-sectional and panel data, illustrating that the unit labor cost, which reflect the external competitiveness of economies was the main determinant of convergence in the European Union and particularly in the Central and Eastern European region between 2000 and 2011. According to Dobrinsky and Havlik, the increase of private credit had positively influenced economic growth at aggregate level, but due to reduced financial intermediation, the results were not favorable in the subgroups of New and Old Members. At the same time, the study suggests that the New Member States made considerable progress not only in terms of income convergence, but also in the case of structural determinants such as labor productivity, competitiveness, export volume and trade composition.

In addition, Stanišić (2012) examined conditional $\beta$-convergence, using the two-stage least squares method based on panel data, illustrating that the GDP per capita growth rates were positively influenced by the level of education, life expectancy at birth, investment, exports and a sound budgetary framework, as reflected by the current account balance. In contrast, the growth rate was inversely correlated with the fertility rate and inflation. Similarly, Rapacki and Próchniak (2019) investigated the factors that influence the catching-up process, taking into consideration variables related to the European Union membership and the economic and social framework. By applying multiple regressions, analysts pointed out that European Union membership has positively influenced income convergence in the Central and Eastern European countries. Moreover, the process of economic growth has been enhanced by the improvement of the institutional quality and by trade and financial integration. Finally, Rapacki and Próchniak concluded that "the convergence process is not automatic", requiring concrete measures by public authorities, especially in terms of strengthening the institutional environment.

\section{Data \& Methodology}

The main purpose of this paper is to study the economic growth patterns in the European Union and two subgroups of countries - the New Member States from Central and Eastern Europe (Bulgaria, Czech Republic, Croatia, Estonia, Hungary, Latvia, Lithuania, Poland, Romania, Slovakia and Slovenia) and the Old Member States group (Austria, Belgium, Denmark, Finland, France, Germany, Greece, Italy, Ireland, Netherlands, Portugal, Spain, Sweden, and United Kingdom). Another objective of the research was to find evidence in favor of income convergence, by taking into consideration the evolution GDP per capita (PPS) between 2000 and 2019. We have excluded from the analysis of conditional $\beta$-convergence Cyprus, Luxembourg and Malta given the large offshore activities that might have biased the estimation. By examining conditional $\beta$-convergence based on panel regressions, we have tried to find a statistically significant relationship between the lagged value of GDP per capita and the subsequent growth rates both at aggregate and subgroup level. In order to control the potential structural differences between Member States, we have included in the regressions equations the gross capital formation (\% of GDP), the volume of exports of goods and services (\% of GDP), the government balance (\% of GDP) and the percentage of population with tertiary studies. Data was obtained from Eurostat and World Bank databases. The description of the variables is presented in Table 1:

Conditional $\beta$-convergence was estimated based on panel data, using ordinary least squares and generalized squares methods with fixed effects, taking into consideration the equation below:

The convergence rate was estimated based on the following equation ${ }^{1}$ :

Table 2 illustrates the statistical description of the variables included in the study of conditional $\beta$-convergence for the three groups of countries: European Union (27), New (11) and Old Member States (14). At a first glance, the minimum and maximum values suggest that the Member States are not homogenous in terms of economic performances. Moreover, there are divergences between the New and Old Member States subgroups, but also within them. The average GDP growth rate at aggregate level was around 3.5\% between 2000 and 2019. However, Ireland experienced an increase of 35\% in 2015 compared to the previous year. In contrast, Latvia experienced

\footnotetext{
${ }^{1} \mathrm{~T}=1$ for panel data
} 
an economic downturn of $17.7 \%$ between 2008 and 2009. The average growth rate was around 5\% among the New Members and 2.2\% for the Old Members. In terms of GDP per capita, Ireland recorded the highest value at Community level (excluding Luxembourg), reaching 60,500 PPS in 2019, while Romania had the lowest performance in 2000 - 5,100 PPS. The average GDP per capita in the European Union was 29,350 PPS, while in the Central and Eastern European group only 16,350 PPS. In the field of investment, as reflected by the gross capital formation indicator, the average value at Community's level was $23 \%$ of GDP. The highest percentage was recorded by Ireland (43.8\%), while Greece was at the opposite pole of the ranking, with a percentage of $10.2 \%$ in 2010. In terms of exports of goods and services (\% of GDP), the Central and Eastern European group experienced higher values compared to the Old Members (57.7\% versus $46.2 \%$ of GDP). The export leader in Central and Eastern Europe was Slovakia, with a percentage of over $90 \%$ of GDP, while Ireland was placed at the top of the ranking of the Old Members' subgroup. Regarding the quality of public finances, reflected by the values of the government balance, the average value at Community level was around $-2.5 \%$. Surpluses of the public balance were recorded by countries such as Finland, Denmark, Ireland, Estonia and Bulgaria, but the minimum was reached by Ireland (-32\%) in 2010. There are also significant differences in the field of education. On average, $22 \%$ of the European citizens had a tertiary level of education in 2019. Higher values were recorded by Ireland and United Kingdom (approximately 40\% in 2019), while the minimum was reached by Romania in $2000(7.5 \%)$.

\section{Results}

Table 3 presents the results of conditional $\beta$-convergence that was estimated using ordinary least squares method with cross-sectional fixed effects. As it results from the empirical literature (Dobrinsky and Havlik, 2014), the fixed effects model offers a solution for the unobserved heterogeneity at cross-sectional level. In order to account for the heteroscedasticity, a frequent vulnerability in the study of economic growth patterns using ordinarily least squares method, the equations were computed using robust standard errors. We found evidence in favor of conditional convergence hypothesis for both European Union and the two subgroups, given the negative relationship between the lagged value of GDP per capita and the annual growth rates. The macroeconomic variables included in the model have the expected influence on the dependent variable, although they are not in all cases statistically significant ( $\mathrm{p}$-value $>10 \%$ ). Consequently, the empirical model confirms the positive impact of investment, exports of goods and services and a positive public balance on economic growth rates between 2000 and 2019. Analyzing the value of the coefficients, we might conclude that growth rate was particularly enhanced by exports and investment. At the same time, the estimated model illustrated that increasing the level of education of the European citizens, an objective included in the Europe 2020 Strategy, had a favorable impact on economic growth. The value of the coefficient of determination suggests that the model explains in a proportion that varies between 36\% (Old Member States) and 56\% (European Union) the variation of the dependent variable.

In order to confirm the influence of the selected explanatory variables, we have estimated the model using generalized least squares method, with cross-sectional fixed effects. We have found strong evidence in favor of the conditional convergence hypothesis both at aggregate and subgroup level based on the negative relationship between the lagged value of GDP per capita and annual growth rates. In contrast with the previous estimate, the convergence rate is higher for the Old Members compared to the Central and Eastern European countries. The model confirms the beneficial influence of investments, reflected by the gross capital formation, exports of goods and services, as well as the importance of maintaining a sound public balance. The study also suggests that the efforts to rise the percentage of the population with tertiary education, as part of the Strategy Europe 2020, had a positive contribution in generating prosperity increases at Community level. The model explains in a proportion of about $70 \%$ the variation of the dependent variable for the European Union, $46 \%$ and $31 \%$ for the estimates for the New and Old Members.

Overall, the empirical study confirms the initial expectations. Regarding the influence of the explanatory variables, we have illustrated that investments have positively influenced economic growth, a conclusion previously reached by analysts such as Próchniak (2011), Stanišić (2012) and Marelli et al. (2019). Similar to the results reached by Stanišić (2012), the analysis suggests that maintaining a balanced budget balance, by avoiding excessive deficits, has fostered the process of economic growth. Last, but not the least, the results confirm that 
the efforts to increase the percentage of population with tertiary education enhanced economic prosperity in the European Union.

\section{Conclusion}

The purpose of this paper was to study the economic growth patterns in the European Union between 2000 and 2019, also conducting a comparative analysis between the New Members from Central and Eastern Europe and the Old Member States. Based on panel data, we have examined conditional $\beta$-convergence, trying to find a statistical significant relationship between the lagged value of GDP per capita and the annual growth rates. By using two estimation methods - ordinary least squares and generalized least squares - we have identified evidence in favor of income convergence both at aggregate and subgroup level. Our study also has some implications in the field of public policy. First of all, investment, reflected by the fixed capital formation indicator, as well as exports of goods and services have proved to be the main determinants of economic growth at Community's level. At the same time, the study indicates that maintaining a surplus budget has a positive influence on economic growth. Consequently, the Member States should avoid increasing the government deficits, a trend that has become more prominent in the context of Covid-19 pandemic. Last but not least, the analysis suggests that achieving the objectives of the Europe 2020 Strategy in terms of increasing the percentage of European citizens with tertiary education had a beneficial effect on economic growth. Consequently, the measures adopted to enhance the economic performances should be coupled with initiatives aiming the social environment, mainly in the field of education. Given the complexity of the economic growth process, the research might be continued by studying the influence of other macroeconomic, social and institutional variables.

Funding: self-funded.

Author contribution: conceptualization: Ana-Maria Holobiuc; data curation: Ana-Maria Holobiuc; formal analysis Ana-Maria Holobiuc; funding acquisition: Ana-Maria Holobiuc; investigation: Ana-Maria Holobiuc; methodology: Ana-Maria Holobiuc; project administration: Ana-Maria Holobiuc; resources: Ana-Maria Holobiuc; software: Ana-Maria Holobiuc; supervision: Ana-Maria Holobiuc; validation: Richard Fast; visualization: Ana-Maria Holobiuc; writing - original draft: Ana-Maria Holobiuc; writing - review \& editing: Ana-Maria Holobiuc.

\section{References}

1. Barro, R. J. \& Sala-i-Martin, X. (1992). Convergence. Journal of Political Economy, 100(2), 223-251. [CrossRef].

2. Chapsa, X. \& Tsanana, E. \& Katrakilidis, C. (2015). Growth and Convergence in the EU-15: More Evidence from the Cohesion Countries. Procedia Economics and Finance, 33, 55-63. [CrossRef].

3. De la Fuente, A. (1997). The empirics of growth and convergence: A selective review. Journal of Economic Dynamics and Control, 21(1), 23-73. [CrossRef].

4. Dobrinsky, R. \& Havlik, P. (2014). Economic Convergence and Structural Change: the Role of Transition and EU Accession. Research Report No. 395. The Vienna Institute for International Economic Studies. Available at: [Link].

5. Duro, E. (2012). Speed of convergence. CEE and Western Balkans countries. International Journal of Scientific \& Engineering Research, 3(4), 1-7. [Google Scholar].

6. Eurostat (2020). Database. [Link].

7. Grossman, G. M. \& Helpman, E. (1994). Endogenous Innovation in the Theory of Growth. Journal of Economic Perspectives, 8(1), 23-44. [CrossRef].

8. Islam, N. (2003). What Have We Learnt From the Convergence Debate? Journal of Economic Surveys, 17, 309-362. [CrossRef].

9. Lucas, R. (1988). On the mechanics of economic development. Journal of Monetary Economics, Elsevier, 22(1), 3-42. [CrossRef].

10. Marelli, E. P., Parisi, M. L. \& Signorelli, M. (2019). Economic convergence in the EU and Eurozone. Journal of Economic Studies, 46(7), 1332-1344. [Google Scholar]. 
11. Matkowski, Z., Próchniak, M., Rapacki, R. (2016). Real Income Convergence between Central Eastern and Western Europe: Past, Present, and Prospects. 33rd Centre for International Research on Economic Tendency Surveys Conference on Economic Tendency Surveys and Economic Policy (September 14 - September 17, 2016). Available from: [Link].

12. Próchniak, M. (2011). Determinants of economic growth in Central and Eastern Europe: the global crisis perspective. Post-Communist Economies, 23(4), 449-468. [CrossRef].

13. Rapacki, R. \& Próchniak, M. (2019). EU membership and economic growth: empirical evidence for the CEE countries. European Journal of Comparative Economics, 16(1), 3-40. [Link].

14. Romer, P. M. (1986). Increasing Returns and Long-run Growth, Journal of Political Economy, University of Chicago Press, 94(5), 1002-1037. [CrossRef].

15. Romer, P. M. (1987). Growth Based on Increasing Returns Due to Specialization. American Economic Review, 77(2), 56-62. [Google Scholar].

16. Romer, P. M. (1989). Human Capital and Growth: Theory and Evidence. NBER Working Paper No. w3173. Massachusetts: National Bureau of Economic Research. [CrossRef].

17. Romer, P. M. (1990). Endogenous Technological Change. The Journal of Political Economy, 98 (5) Part 2: The Problem of Development: A Conference of the Institute for the Study of Free Enterprise Systems, S71S102. [CrossRef].

18. Solow, R. M. (1956). A Contribution to the Theory of Economic Growth. The Quarterly Journal of Economics, 70(1), 65-94. [CrossRef].

19. Stanišić, N. (2012). The effects of the economic crisis on income convergence in the European Union. Acta Oeconomica, 62(2), 161-182. [CrossRef].

20. Swan, T. W. (1956). Economic growth and capital accumulation. Economic Record, 32 (2), 334-361. [CrossRef].

21. Vojinović, B., Acharya, S., Próchniak, M. (2009). Convergence Analysis Among the Ten European Transition Economies. Hitotsubashi Journal of Economics, 50(2), 17-35. [CrossRef].

22. World Bank (2020). Data. Available from: [Link].

\section{Appedices}

Table 1. Variables, definitions and source

\begin{tabular}{|c|c|c|c|}
\hline Variable & Description & Source & Expected influence \\
\hline GDP per capita & $\begin{array}{l}\text { GDP per capita at current prices } \\
\text { (PPS) }\end{array}$ & Eurostat & Lagged value - negative \\
\hline Gross capital formation (GCF) & $\begin{array}{l}\text { Gross capital formation ( } \% \\
\text { GDP) }\end{array}$ & World Bank & Positive \\
\hline Exports of goods and services & $\begin{array}{l}\text { Sum of exports of goods and } \\
\text { services (\% GDP) }\end{array}$ & World Bank & Positive \\
\hline Government balance (GB) & $\begin{array}{l}\text { Government deficit/surplus (\% } \\
\text { GDP) }\end{array}$ & Eurostat & Positive \\
\hline $\begin{array}{l}\text { Population with tertiary } \\
\text { education (PTE) }\end{array}$ & $\begin{array}{l}\text { Population with tertiary } \\
\text { education (levels 5-8) (\% total } \\
\text { population) }\end{array}$ & Eurostat & Positive \\
\hline
\end{tabular}

Source: Author's presentation.

$$
\ln \left(\Delta y_{i, t}\right)=a+\beta_{1} \ln \left(y_{i, t-1}\right)+\beta_{2} \ln (G C F)+\beta_{3} \ln (\text { Exports })+\beta_{4}(G B)+\beta_{5} \ln (P T E)+u_{i, t}
$$

$Y_{i, t}=$ GDP per capita

$u_{i, t}=$ residuals

$\mathrm{t}=1, \ldots, \mathrm{T}$ (period)

$\mathrm{i}=1, \ldots, \mathrm{N}$ (cross-sections) 
$\beta=-\frac{1}{T} \ln \left(1+\beta_{1} T\right)$

Table 2. Statistical description

\begin{tabular}{|c|c|c|c|c|c|c|c|}
\hline Variable & Group & Mean & Median & Max & Min & St. dev. & $\begin{array}{c}\text { No. of } \\
\text { obs. }\end{array}$ \\
\hline \multirow{3}{*}{$\begin{array}{l}\text { Annual GDP } \\
\text { per capita } \\
\text { growth rate }\end{array}$} & $\begin{array}{l}\text { European } \\
\text { Union }\end{array}$ & 0.0349 & 0.0353 & 0.3215 & -0.1771 & 0.0455 & 475 \\
\hline & $\begin{array}{l}\text { New member } \\
\text { states }\end{array}$ & 0.0514 & 0.0523 & 0.1718 & -0.1771 & 0.0491 & 209 \\
\hline & $\begin{array}{l}\text { Old member } \\
\text { states }\end{array}$ & 0.0222 & 0.0250 & 0.3215 & -0.0993 & 0.0378 & 266 \\
\hline \multirow[t]{3}{*}{ GDP per capita } & $\begin{array}{l}\text { European } \\
\text { Union }\end{array}$ & 29,350 & 23,650 & 60,500 & 5,100 & 8,802 & 500 \\
\hline & $\begin{array}{l}\text { New member } \\
\text { states }\end{array}$ & 16,350 & 16,300 & 29,100 & 5,100 & 5,243 & 220 \\
\hline & $\begin{array}{l}\text { Old member } \\
\text { states }\end{array}$ & 29,350 & 28,850 & 60,500 & 16,500 & 6,510 & 280 \\
\hline \multirow[t]{3}{*}{$\begin{array}{l}\text { Gross capital } \\
\text { formation }\end{array}$} & $\begin{array}{l}\text { European } \\
\text { Union }\end{array}$ & 23.1752 & 22.7094 & 43.8210 & 10.2170 & 4.5496 & 500 \\
\hline & $\begin{array}{l}\text { New member } \\
\text { states }\end{array}$ & 24.8064 & 24.1355 & 41.4491 & 12.3711 & 4.7864 & 220 \\
\hline & $\begin{array}{l}\text { Old member } \\
\text { states }\end{array}$ & 21.8936 & 22.1898 & 43.8210 & 10.2170 & 3.9104 & 280 \\
\hline \multirow{3}{*}{$\begin{array}{lr}\begin{array}{l}\text { Exports } \\
\text { goods }\end{array} & \text { of } \\
\text { services } & \end{array}$} & $\begin{array}{l}\text { European } \\
\text { Union }\end{array}$ & 51.3186 & 46.2500 & 126.1000 & 18.5000 & 21.5469 & 500 \\
\hline & $\begin{array}{l}\text { New member } \\
\text { states }\end{array}$ & 57.7850 & 58.0000 & 96.2000 & 21.6000 & 18.5415 & 220 \\
\hline & $\begin{array}{l}\text { Old member } \\
\text { states }\end{array}$ & 46.2378 & 40.4500 & 126.1000 & 18.5000 & 22.3970 & 280 \\
\hline \multirow[t]{3}{*}{$\begin{array}{l}\text { Government } \\
\text { balance }\end{array}$} & $\begin{array}{l}\text { European } \\
\text { Union }\end{array}$ & -2.5062 & -2.3000 & 6.9000 & -32.1000 & 3.5007 & 500 \\
\hline & $\begin{array}{l}\text { New member } \\
\text { states }\end{array}$ & -2.6550 & -2.3500 & 2.9000 & -14.6000 & 2.8394 & 220 \\
\hline & $\begin{array}{l}\text { Old member } \\
\text { states }\end{array}$ & -2.3892 & -2.2500 & 6.9000 & -32.1000 & 3.9444 & 280 \\
\hline \multirow{3}{*}{$\begin{array}{l}\text { Population } \\
\text { with tertiary } \\
\text { education }\end{array}$} & $\begin{array}{l}\text { European } \\
\text { Union }\end{array}$ & 22.6449 & 22.6000 & 40.7000 & 7.5000 & 7.9021 & 490 \\
\hline & $\begin{array}{l}\text { New member } \\
\text { states }\end{array}$ & 19.5160 & 18.9000 & 37.9000 & 7.5000 & 7.0240 & 218 \\
\hline & $\begin{array}{l}\text { Old member } \\
\text { states }\end{array}$ & 25.1525 & 26.1500 & 40.7000 & 7.5000 & 7.6799 & 272 \\
\hline
\end{tabular}

Source: Author's computation. 
Table 3. Conditional $\beta$-convergence (Ordinary least squares - fixed effects)

\begin{tabular}{|l|c|c|c|}
\hline \multicolumn{3}{|c|}{ Dependent variable: Annual GDP per capita growth rate between 2000 and 2019 } \\
\hline \multicolumn{1}{|c|}{ Group } & European Union & New Member States & Old Member States \\
\hline No. of obs./ Variable & 468 & 208 & 260 \\
\hline C & $0.4888^{*}$ & $0.3399^{* *}$ & $\left(0.9903^{*}\right.$ \\
& $(0.1501)$ & $(0.1537)$ & $(2.3451)$ \\
& $(3.2544)$ & $(2.2104)$ & $-0.2388^{*}$ \\
\hline GDP per capita (-1) & $-0.1718^{*}$ & $-0.1491^{*}$ & $(0.0560)$ \\
& $(0.0465)$ & $(0.0491)$ & $(-4.2602)$ \\
\hline Gross capital formation & $(-3.6916)$ & $(-3.0323)$ & $0.1767^{*}$ \\
& $0.1468^{*}$ & $0.1395^{*}$ & $(0.0397)$ \\
& $(0.0381)$ & $(0.0324)$ & $(4.4426)$ \\
\hline Exports of goods and services & $(3.8464)$ & $(4.2984)$ & 0.2131 \\
& $0.1881^{*}$ & $0.1662^{* * *}$ & $(0.0495)$ \\
& $(0.0668)$ & $(0.0873)$ & $(4.3033)$ \\
\hline Government balance & $(2.8141)$ & $(1.9034)$ & 0.0001 \\
& 0.0014 & $0.0038^{* * *}$ & $(0.0008)$ \\
& $(0.0011)$ & $(0.0020)$ & $(0.1804)$ \\
\hline Population with tertiary & $(1.2417)$ & $(1.8411)$ & $0.0454^{* *}$ \\
education & 0.0260 & 0.0147 & $(0.0211)$ \\
& $(0.0158)$ & $(0.0225)$ & $(2.1480)$ \\
\hline Prob(F-statistic) & $(1.6436)$ & $(0.6529)$ & 0.0000 \\
\hline R-squared & 0.0000 & 0.0000 & 0.4038 \\
\hline Adjusted R-squared & 0.5286 & 0.5566 & 0.3592 \\
\hline
\end{tabular}

Source: Author's computation.

Note: $*$ - p-value < 1\%; $* *$ - p-value $<5 \%$; *** - p-value < 10\%; standard errors and t-statistics in parentheses.

Table 4. Conditional $\beta$-convergence (Generalized least squares -fixed effects)

\begin{tabular}{|l|c|c|c|}
\hline \multicolumn{3}{|c|}{ Dependent variable: Annual GDP per capita growth rate between 2000 and 2019 } \\
\hline \multicolumn{2}{|c|}{ Gethod: Generalized least squares - cross-section fixed effects } & New Member States & Old Member States \\
\hline No. of obs./ Variable & European Union & 208 & 260 \\
\hline C & 468 & $0.4459^{*}$ & $0.9769^{*}$ \\
& $0.5705^{*}$ & $(0.1652)$ & $(0.3111)$ \\
& $(0.1823)$ & $(2.6982)$ & $(3.1394)$ \\
\hline GDP per capita (-1) & $(3.1293)$ & $-0.1668^{*}$ & $-0.2510^{*}$ \\
& $-0.1875^{*}$ & $(0.0509)$ & $(0.0535)$ \\
& $(0.0466)$ & $(-3.2739)$ & $(-4.6861)$ \\
\hline Gross capital formation & $(-4.0245)$ & $0.1396^{*}$ & $0.1953^{*}$ \\
& $0.1557^{*}$ & $(0.0300)$ & $(0.0448)$ \\
& $(0.0373)$ & $(4.6453)$ & $(4.3577)$ \\
\hline Exports of goods and services & $(4.1671)$ & $0.1807 * *$ & $0.2375^{*}$ \\
& $0.2007^{*}$ & $(0.0808)$ & $(0.0571)$ \\
& $(0.0637)$ & $(2.2349)$ & $(4.1559)$ \\
\hline Government balance & $(3.1503)$ & 0.0027 & 0.0003 \\
& 0.0011 & $(0.0016)$ & $(0.0010)$ \\
\hline Population with tertiary & $(0.0010)$ & $(1.6002)$ & $(0.3445)$ \\
education & $(1.0787)$ & 0.0158 & $0.0420^{* *}$ \\
& $0.0253^{* * *}$ & $(0.0177)$ & $(0.0165)$ \\
\hline Prob(F-statistic) & $(0.0134)$ & $(0.8951)$ & $(2.5354)$ \\
\hline R-squared & $(1.8848)$ & 0.0000 & 0.0000 \\
\hline Adjusted R-squared & 0.0000 & 0.5700 & 0.5036 \\
\hline
\end{tabular}

Source: Author's computation.

Note: $*$ - p-value $<1 \% ; * *$ - p-value $<5 \%$; $* * *$ - p-value $<10 \%$; standard errors and t-statistics in parentheses. 